\title{
THE MODE OF EXCRETION OF CREATINE AND CREATINE METABOLISM IN THYROID DISEASE ${ }^{1}$
}

\author{
By NICHOLAS A. TIERNEY aNd JOHN P. PETERS \\ (From the Department of Internal Medicine, Yale University School of Medicine, and the \\ Medical Service of the New Haven Hospital, New Haven)
}

(Received for publication January 25, 1943)

The yellow color yielded by the Jaffe reaction, which is commonly employed for the determination of creatinine and creatine, is not highly specific and is ill-adapted to visual colorimetry. For the measurement of the comparatively gross quantities of creatinine and creatine excreted in the urine, it has proved quite accurate; but the small amounts of creatinine found in normal blood can be measured only with uncertainty. For creatine of serum, it has proved even more unsatisfactory than for creatinine. So slight is the increase in color produced by alkaline picrate after serum filtrates are exposed to acid and heat that the very presence of creatine in normal serum has been doubted ( 1 to 3 ). In the plasma of infants and of women who excreted creatine in the urine, Hunter and Campbell (1) and Wilson and Plass (2) detected appreciable increments of chromogenic material after treatment aimed to convert creatine to creatinine. This led them to the tentative conclusion that creatinuria marked the appearance of creatine in the serum of which it was not a normal component.

Discouraged by these experiences, subsequent observers have confined their attentions to studies of the excretion of creatine in the urine, in which it appears in measurable quantities and without appreciable amounts of interfering chromogenic substances. Consequently, opinions about the metabolism of this substance, especially in human subjects, are largely based on inference. The recent presentation by Peters (4) of a procedure adapted to the Evelyn-Molloy photoelectric colorimeter has made it possible to measure creatine in serum with reasonable accuracy and therefore to examine the relation of creatinuria to the concentration of creatine in blood serum.

The present paper deals with the mode of excretion of creatine by normal adults and the na-

1 Aided by a grant from the Fluid Research Fund of the Yale University School of Medicine. ture of the creatinuria of patients with diseases of the thyroid.

\section{METHODS}

Blood serum and urine were analyzed for creatinine and creatine by the Folin (5) method with the modifications devised by Peters (4) to adapt it to the Evelyn-Molloy photoelectric colorimeter. The most important of these are: (1) the use of a concentrated, but unsaturated solution of picric acid, containing 11.75 grams per liter instead of a saturated solution; and (2) the omission of hydrochloric acid as a dehydrating agent, since it was found that in tungstate filtrates, creatine is quantitatively converted to creatinine at autoclave temperature without the addition of acid. The error of the method does not exceed 0.1 mgm. per cent.

Because of the variability of the concentrations of creatine and creatinine in urine, difficulty was at first experienced in bringing the color within the range of intensity suitable for the colorimeter. This was obviated by diluting all urines to a specific gravity of 1.010. From this diluted urine, a 1 to 20 dilution was made. This procedure brings the concentrations of creatine and creatinine regularly within the optimum colorimetric range.

In a certain number of experiments, blood and urine were collected at approximately the same time, but the urine was not collected over any specified interval of time. The rate of excretion in these instances could not be accurately measured. In order to secure a more uniform basis of comparison, the excretion of creatinine and creatine in these experiments was estimated in terms of their concentration in urine of a specific gravity of 1.010 .

In another series in which urine was collected over an accurately timed interval, excretion was estimated in terms of milligrams of creatine or creatinine excreted per hour.

The effect of ingestion of creatine was examined in a certain number of normal persons and patients. After a sample of blood had been taken and the bladder had been emptied by voiding, the subject was given 1 gram of creatine (equivalent to 0.864 gram of creatinine) dissolved in water. Blood was again withdrawn 30,60 , and 180 minutes and urine was collected 60,120 , and $180 \mathrm{~min}$ utes after the ingestion of the creatine. All specimens of blood and urine were analyzed for both creatine and creatinine. In these experiments, clearances of endogenous creatinine and of creatine were estimated in the fasting period and the third hour after ingestion of creatine. For the latter, the geometric mean of the concen- 
trations of creatine and creatinine at the beginning and end of the hour was used.

All patients were studied in the postabsorptive state, normal subjects at least 2 hours after a "creatine-free" breakfast.

\section{RESULTS}

Normal male subjects. The serum creatine of 12 normal males varied from 0.17 to $0.50 \mathrm{mgm}$. per cent and the serum creatinine from 1.05 to $1.65 \mathrm{mgm}$. per cent (see Table I). No creatine was found in the urine of any of the 12 , nor in the urine of 10 other normal males.

TABLE I

Normal male cases

\begin{tabular}{l|l|l|l}
\hline \multirow{2}{*}{ Case } & \multicolumn{2}{|c|}{ Serum } & \multirow{2}{*}{ Urine creatine } \\
\cline { 2 - 3 } & Creatine & Creatinine & \\
\cline { 2 - 3 } & \multicolumn{3}{|c|}{ mgm. per cent } \\
RS & 0.23 & 1.50 & 0 \\
HT & 0.45 & 1.20 & 0 \\
WD & 0.58 & 1.05 & 0 \\
FS & 0.41 & 1.65 & 0 \\
AB & 0.29 & 1.10 & 0 \\
WK & 0.17 & 1.40 & 0 \\
NT & 0.52 & 1.40 & 0 \\
AG & 0.17 & 1.40 & 0 \\
BR & 0.41 & 1.30 & 0 \\
AT & 0.35 & 1.20 & 0 \\
HP & 0.40 & 1.25 & 0 \\
ER & 0.46 & 1.55 & 0 \\
\hline
\end{tabular}

TABLE II

Normal female cases

\begin{tabular}{|c|c|c|c|c|}
\hline \multirow{2}{*}{ Case } & \multicolumn{2}{|c|}{ Serum } & \multicolumn{2}{|c|}{$\begin{array}{l}\text { Urine } \\
\text { sp. gr. } 1.010\end{array}$} \\
\hline & Creatine & Creatinine & Creatine & Creatinine \\
\hline $\begin{array}{l}\text { MB } \\
\text { MA } \\
\text { RW } \\
\text { LM } \\
\text { AR } \\
\text { AC } \\
\text { ACo. } \\
\text { LC } \\
\text { ACav. } \\
\text { RA } \\
\text { RV } \\
\text { PA }\end{array}$ & $\begin{array}{l}\quad m g m . \\
0.81 \\
0.64 \\
0.75 \\
0.93 \\
0.70 \\
0.81 \\
0.41 \\
0.75 \\
0.35 \\
0.64 \\
0.70 \\
0.46\end{array}$ & $\begin{array}{r}\text { cent } \\
1.50 \\
1.05 \\
1.35 \\
1.20 \\
0.90 \\
1.00 \\
1.15 \\
0.95 \\
0.90 \\
1.15 \\
0.90 \\
1.00\end{array}$ & $\begin{array}{c}m g m . \\
12.8 \\
5.8 \\
2.4 \\
9.2 \\
5.8 \\
14.0 \\
0 \\
9.2 \\
0 \\
9.8 \\
24.3 \\
0\end{array}$ & $\begin{array}{r}\text { cent } \\
50 \\
22 \\
45 \\
47 \\
78 \\
42 \\
68 \\
54 \\
94 \\
86 \\
59 \\
62\end{array}$ \\
\hline $\begin{array}{l}\text { LD } \\
\text { EU } \\
\text { TH } \\
\text { OD } \\
\text { PH } \\
\text { DH } \\
\text { SR }\end{array}$ & $\begin{array}{l}0.58 \\
0.81 \\
0.58 \\
0.46 \\
0.46 \\
0.45 \\
0.75\end{array}$ & $\begin{array}{l}1.05 \\
1.30 \\
0.95 \\
1.00 \\
0.85 \\
1.20 \\
1.30\end{array}$ & $\begin{array}{c}m g m . \\
3.9 \\
5.2 \\
0.5 \\
0 \\
0 \\
0 \\
1.67\end{array}$ & $\begin{array}{r}\text { hour } \\
53.5 \\
52.2 \\
32.5 \\
40.1 \\
28.0 \\
55.5 \\
34.7\end{array}$ \\
\hline
\end{tabular}

Normal female subjects. The serum creatine of 19 normal women ranged from 0.35 to 0.93 mgm. per cent and the serum creatinine from 0.90 to $1.50 \mathrm{mgm}$. per cent (see Table II). The urine of all but 6 of the women contained creatine. The serum creatine of these 6 varied from 0.35 to 0.46 mgm. per cent, within the range covered by the males; in the 13 who had creatinuria, it was never lower than $0.58 \mathrm{mgm}$. per cent.

Peroneal muscular atrophy. In one patient with peroneal muscular atrophy and profuse creatinuria, the serum creatine was elevated to the high figure of $1.51 \mathrm{mgm}$. per cent.

Patients with thyroid disease. Three men and 8 women with clinical evidences of hyperthyroidism, high serum iodine, and high basal metabolism, were studied before and after a course of treatment with iodine (see Table III). The concentration of creatine in the serum of 3 of the

TABLE III

Hyperthyroid series

\begin{tabular}{|c|c|c|c|c|c|c|}
\hline \multirow{2}{*}{ Patient } & \multirow{2}{*}{ Treatment } & \multirow{2}{*}{$\begin{array}{c}\text { Basal } \\
\text { metab- } \\
\text { olism }\end{array}$} & \multicolumn{2}{|c|}{ Serum } & \multicolumn{2}{|c|}{$\begin{array}{l}\text { Urine } \\
\text { sp. gr. } 1.010\end{array}$} \\
\hline & & & $\underset{\text { tine }}{\text { Crea- }}$ & $\begin{array}{c}\text { Creati- } \\
\text { nine }\end{array}$ & $\begin{array}{c}\text { Crea- } \\
\text { tine }\end{array}$ & $\begin{array}{c}\text { Creati- } \\
\text { nine }\end{array}$ \\
\hline GB & $\begin{array}{l}\text { Before Lugols } \\
\text { After Lugols }\end{array}$ & $\begin{array}{c}\text { per cent } \\
+35 \\
+1\end{array}$ & $\begin{array}{l}\text { mgm. } \\
1.04 \\
0.40\end{array}$ & \begin{tabular}{|l|} 
ser cent \\
1.00 \\
0.80
\end{tabular} & $\begin{array}{c}m g m . \\
16.2 \\
0\end{array}$ & $\begin{array}{c}\text { ser cent } \\
34 \\
35\end{array}$ \\
\hline LG & $\begin{array}{l}\text { Before Lugols } \\
\text { After Lugols }\end{array}$ & $\begin{array}{l}+78 \\
+37\end{array}$ & $\begin{array}{l}0.70 \\
0.58\end{array}$ & $\begin{array}{l}0.95 \\
0.95\end{array}$ & $\begin{array}{r}21.0 \\
0\end{array}$ & $\begin{array}{l}42 \\
46\end{array}$ \\
\hline $\mathrm{PB}^{*}$ & $\begin{array}{l}\text { Before Lugols } \\
\text { After Lugols }\end{array}$ & $\begin{array}{l}+50 \\
+15\end{array}$ & $\begin{array}{l}0.70 \\
0.46\end{array}$ & $\begin{array}{l}0.95 \\
1.20\end{array}$ & $\begin{array}{l}8.1 \\
3.5\end{array}$ & $\begin{array}{l}58 \\
40\end{array}$ \\
\hline RL & $\begin{array}{l}\text { Before Lugols } \\
\text { After Lugols }\end{array}$ & $\begin{array}{r}+26 \\
+4\end{array}$ & $\begin{array}{l}0.81 \\
0.60\end{array}$ & $\begin{array}{l}1.60 \\
1.55\end{array}$ & $\begin{array}{c}12.25 \\
6.3\end{array}$ & $\begin{array}{l}67.2 \\
61.2\end{array}$ \\
\hline SH & $\begin{array}{l}\text { Before Lugols } \\
\text { After Lugols }\end{array}$ & $\begin{array}{l}+50 \\
+22\end{array}$ & $\begin{array}{l}1.10 \\
0.58\end{array}$ & $\begin{array}{l}1.00 \\
0.70\end{array}$ & $\begin{array}{c}\text { mgm. } \\
29.2 \\
3.5\end{array}$ & $\begin{array}{r}\text { Der hour } \\
35.8 \\
43.5\end{array}$ \\
\hline $\mathrm{BL}^{*}$ & $\begin{array}{l}\text { Before Lugols } \\
\text { After Lugols }\end{array}$ & +31 & $\begin{array}{l}0.81 \\
0.58\end{array}$ & $\begin{array}{l}0.90 \\
0.95\end{array}$ & $\begin{array}{c}26.3 \\
2.32\end{array}$ & $\begin{array}{l}73.4 \\
70\end{array}$ \\
\hline CF & $\begin{array}{l}\text { Before Lugols } \\
\text { After Lugols }\end{array}$ & $\begin{array}{l}+48 \\
+19\end{array}$ & $\begin{array}{l}0.87 \\
0.64\end{array}$ & $\begin{array}{l}0.85 \\
0.95\end{array}$ & $\begin{array}{l}4.1 \\
2.15\end{array}$ & $\begin{array}{l}41.5 \\
51.1\end{array}$ \\
\hline HS $^{*}$ & Before Lugols & +22 & 0.29 & 1.05 & $\mathbf{0}$ & 1100 \\
\hline SG & $\begin{array}{l}\text { Before Lugols } \\
\text { After Lugols }\end{array}$ & $\begin{array}{l}+68 \\
+35\end{array}$ & $\begin{array}{l}1.32 \\
1.16\end{array}$ & $\begin{array}{l}1.00 \\
0.70\end{array}$ & $\begin{array}{l}36.0 \\
18.9\end{array}$ & $\begin{array}{l}28.7 \\
38.3\end{array}$ \\
\hline SD & $\begin{array}{l}\text { Before Lugols } \\
\text { After Lugols }\end{array}$ & $\begin{array}{l}+44 \\
+27\end{array}$ & $\begin{array}{l}0.93 \\
0.98\end{array}$ & $\begin{array}{l}0.85 \\
0.80\end{array}$ & $\begin{array}{l}30.8 \\
32.4\end{array}$ & $\begin{array}{l}70.2 \\
68.0\end{array}$ \\
\hline LN & $\begin{array}{l}\text { Before Lugols } \\
\text { After Lugols }\end{array}$ & $\begin{array}{l}+46 \\
+29\end{array}$ & $\begin{array}{l}0.70 \\
0.87\end{array}$ & $\begin{array}{l}0.80 \\
0.85\end{array}$ & $\begin{array}{l}2.8 \\
3.7\end{array}$ & $\begin{array}{l}60.2 \\
23.2\end{array}$ \\
\hline
\end{tabular}

* Male patients. 
TABLE IV

Effect of ingested creatine on serum and urine creatine

\begin{tabular}{|c|c|c|c|c|c|c|c|c|c|c|c|}
\hline \multirow{2}{*}{$\underset{\text { ject }}{\text { Sub- }}$} & \multirow{2}{*}{$\begin{array}{l}\text { Experi- } \\
\text { ment* }\end{array}$} & \multicolumn{4}{|c|}{ Serum creatine } & \multicolumn{6}{|c|}{ Urine creatine } \\
\hline & & Fasting & $\stackrel{30}{\text { minutes }}$ & $\stackrel{60}{\text { minutes }}$ & $\begin{array}{c}180 \\
\text { minutes }\end{array}$ & Fasting & $\begin{array}{l}\text { First } \\
\text { hour }\end{array}$ & $\begin{array}{l}\text { Second } \\
\text { hour }\end{array}$ & $\begin{array}{l}\text { Third } \\
\text { hour }\end{array}$ & Total & $\begin{array}{l}\text { Of dose } \\
\text { given }\end{array}$ \\
\hline & & \multicolumn{4}{|c|}{ mgm. per cent of creatinine } & \multicolumn{4}{|c|}{ mgm. creatinine per hour } & mgm. & per cent \\
\hline
\end{tabular}

NORMAL MALES

\begin{tabular}{|c|c|c|c|c|c|c|c|c|c|c|c|}
\hline $\begin{array}{l}\text { AT } \\
\text { RS }\end{array}$ & $\begin{array}{l}\mathbf{a} \\
\mathbf{a}\end{array}$ & $\begin{array}{l}0.40 \\
0.35\end{array}$ & $\begin{array}{l}1.86 \\
0.99\end{array}$ & $\begin{array}{l}1.33 \\
1.16\end{array}$ & $\begin{array}{l}0.64 \\
0.41\end{array}$ & $\begin{array}{l}0 \\
0\end{array}$ & $\begin{array}{l}6.3 \\
3.5\end{array}$ & $\begin{array}{l}8.2 \\
5.8\end{array}$ & $\begin{array}{l}6.9 \\
6.9\end{array}$ & $\begin{array}{l}21.4 \\
16.2\end{array}$ & $\begin{array}{l}2 \\
2\end{array}$ \\
\hline \multicolumn{12}{|c|}{ NORMAL FEMALES } \\
\hline $\begin{array}{l}\text { SR } \\
\text { MM } \\
\text { PH } \\
\text { DH }\end{array}$ & $\begin{array}{l}\mathbf{a} \\
\mathbf{a} \\
\mathbf{a} \\
\mathbf{a}\end{array}$ & $\begin{array}{l}0.75 \\
0.58 \\
0.46 \\
0.46\end{array}$ & $\begin{array}{l}1.74 \\
2.40 \\
2.55 \\
0.91\end{array}$ & $\begin{array}{l}2.84 \\
1.80 \\
2.55 \\
1.74\end{array}$ & $\begin{array}{l}1.33 \\
0.92 \\
0.93 \\
1.16\end{array}$ & $\begin{array}{l}1.7 \\
1.6 \\
0 \\
0\end{array}$ & $\begin{array}{r}50.5 \\
73.0 \\
65.0 \\
7.1\end{array}$ & $\begin{array}{l}70.1 \\
80.3 \\
81.2 \\
55.5\end{array}$ & $\begin{array}{l}23.1 \\
39.0 \\
23.0 \\
57.0\end{array}$ & $\begin{array}{l}145.4 \\
193.9 \\
169.2 \\
119.6\end{array}$ & $\begin{array}{l}17 \\
22 \\
20 \\
14\end{array}$ \\
\hline
\end{tabular}

Hyperthyroid patients

MALES

\begin{tabular}{|c|c|c|c|c|c|c|c|c|c|c|c|}
\hline HS & $\mathbf{a}$ & 0.29 & 0.70 & 0.69 & 0.29 & 0 & 2.3 & 0.9 & 0 & 3.2 & 0.3 \\
\hline \multicolumn{12}{|c|}{ FEMALES } \\
\hline $\begin{array}{l}\text { SH } \\
\text { SD } \\
\text { SG } \\
\text { LN }\end{array}$ & $\begin{array}{l}\mathbf{a} \\
\mathbf{p} \\
\mathbf{a} \\
\mathbf{p} \\
\mathbf{a} \\
\mathbf{p} \\
\mathbf{a} \\
\mathbf{p}\end{array}$ & $\begin{array}{l}1.10 \\
0.58 \\
0.93 \\
0.98 \\
1.32 \\
1.16 \\
0.70 \\
0.87\end{array}$ & $\begin{array}{l}4.23 \\
2.09 \\
1.62 \\
2.49 \\
2.50 \\
2.26 \\
1.71 \\
3.71\end{array}$ & $\begin{array}{l}3.14 \\
2.32 \\
2.55 \\
3.13 \\
2.32 \\
3.07 \\
2.70 \\
2.67\end{array}$ & $\begin{array}{l}1.98 \\
1.32 \\
1.74 \\
2.78 \\
2.61 \\
2.50 \\
1.45 \\
1.51\end{array}$ & $\begin{array}{r}29.2 \\
3.5 \\
30.8 \\
32.4 \\
28.8 \\
18.9 \\
2.8 \\
3.7\end{array}$ & $\begin{array}{r}208.0 \\
78.2 \\
68.5 \\
85.5 \\
107.5 \\
92.3 \\
10.4 \\
75.4\end{array}$ & $\begin{array}{r}51.0 \\
118.5 \\
102.0 \\
143.5 \\
150.0 \\
167.0 \\
35.7 \\
106.0\end{array}$ & $\begin{array}{r}57.4 \\
60.0 \\
92.0 \\
71.0 \\
138.0 \\
87.8 \\
34.5 \\
66.5\end{array}$ & $\begin{array}{r}345.6 \\
260.2 \\
294.3 \\
332.4 \\
424.3 \\
366.0 \\
83.4 \\
251.6\end{array}$ & $\begin{array}{l}40 \\
30 \\
34 \\
38 \\
49 \\
42 \\
10 \\
29\end{array}$ \\
\hline
\end{tabular}

MYXEDEMA

\begin{tabular}{l|l|l|l|l|l|l|l|l|l|l|l}
\hline $\mathrm{AL}$ & $\mathrm{a}$ & 0.35 & 2.08 & 2.78 & 1.22 & 0 & 57.5 & 66.0 & 24.2 & 147.7 & 17 \\
\hline
\end{tabular}

* $a=$ before, $p=$ after iodine therapy.

female subjects, GB, SH, and SG, was higher than the highest value found in the normal women; in the remaining 3 , it fell within the upper limits of the normal female range. All the patients had creatinuria. Of the 3 male patients, 2 had creatinuria with definite elevation of serum creatine; the third had normal serum creatine and no creatinuria.

After a course of iodine, the serum creatine fell significantly in 6 females and the 2 males who had creatinuria. All these patients responded well to treatment. The serum creatine of the last 2 patients in Table III did not fall-in fact in the last, LN, it rose slightly. The basal metabolism also declined less in these 2 than in the others.

The intensity of creatinuria in the whole series, before and after iodine, bore a rough relation to the concentration of creatine in the serum. After iodine, it disappeared in 2 patients and definitely diminished in 6 , the same subjects in whom serum creatine fell; in the other 2 , it rose equivocally. In the 2 instances in which creatinuria disappeared, serum creatine fell to 0.40 and $0.58 \mathrm{mgm}$. per cent, respectively. In 2 others, slight creatinuria persisted with a serum creatine of $0.58 \mathrm{mgm}$. per cent. In the male patient, $\mathrm{PB}$, it persisted after serum creatine had fallen to $0.46 \mathrm{mgm}$. per cent. This is the only occasion in the whole series that creatine was found in the urine when its concentration in the serum was lower than 0.58 mgm. per cent.

As far as can be judged from figures in Tables 
II and III, the relation of urinary creatinine to serum creatine in normals is indistinguishable from the same relation in patients with hyperthyroidism.

Effect of ingested creatine on serum and urine. The results of these experiments appear in $\mathrm{Ta}$ ble IV. After the ingestion of 1 gram of creatine, the serum creatine rose, reaching its peak regularly within 1 hour, usually within 30 minutes. In the 2 normal males, the curve fell off again quite rapidly, to return to the normal range, though not quite to its initial concentration, by the end of 3 hours. Only minute amounts of creatine were excreted in the urine during this period: $16 \mathrm{mgm}$. by one subject, $21 \mathrm{mgm}$. by the other. The hyperthyroid male, $\mathrm{SH}$, who had no fasting creatinuria, reacted in a similar manner.

The curves of the 4 normal females rose to a variable extent, usually higher than the male curves, and all remained elevated longer, being distinctly above the initial level at the end of 3 hours. This was true, not only of the 2 subjects who had initial creatinuria, but also of the 2 who did not. The women also excreted far larger amounts of creatine in the urine than the men did: from 145 to $194 \mathrm{mgm}$. as creatinine, averaging 174 mgm. or 20 per cent of the dose given. In 2 of the $4, \mathrm{PH}$ and $\mathrm{DH}$, the initial concentration of creatine in the serum was within normal male limits and the urine was free from creatine. Nevertheless, these subjects had far more sustained hypercreatinemia and excreted far more creatine than the males did after ingestion of creatine.

The initial curves of 2 of the hyperthyroid women, $\mathrm{SH}$ and SG, were definitely higher and more sustained than those of the normal women. These patients also excreted the largest quantities of creatine, 346 and $424 \mathrm{mgm}$., respectively. The other 2 had initial curves that did not differ appreciably from those of the normal females. Nevertheless, SD excreted $293 \mathrm{mgm}$. of creatine, $100 \mathrm{mgm}$. more than the highest of the normal women. The explanation probably lies in the fact that her hypercreatinemia persisted longer. LN, with the lowest fasting creatine, had an excretion altogether within normal limits. In the first patient, $\mathrm{SH}$, after iodine therapy, the fasting serum creatine, the creatine curve, and the urine creatine fell together. In SD, with little or no change in fasting creatine, the creatine curves and excretions also remained comparatively unaltered. In $\mathrm{LN}$, with a slight elevation of the fasting creatine, the curve and excretion rose strikingly.

One woman with classical, untreated, spontaneous myxedema was studied. Besides typical signs and symptoms, she had low basal metabolism and serum iodine and high serum cholesterol. Her fasting serum creatine was $0.35 \mathrm{mgm}$. per cent, low for a woman and well down in the normal male range, and the fasting urine was free from creatine. After the ingestion of creatine, however, the serum creatine curve rose to $2.78 \mathrm{mgm}$. per cent and remained elevated at 3 hours, resembling the curves of normal women with far higher initial creatines. She also excreted in the urine 148 mgm. of creatine, about the same amount excreted by normal women.

\section{DISCUSSION}

Because of the non-specificity of the Jaffe reaction, the question was raised whether the chromogenic material in plasma was actually creatinine. This doubt has now been largely resolved, especially since Miller and Dubos (6) proved that 80 to 100 per cent of the chromogenic material in plasma is destroyed by an enzyme that acts specifically upon creatinine. The specificity of the reaction for creatine may be questioned on similar grounds. Baker and Miller (7) have, by similar methods, demonstrated that there is creatine in whole blood, but have published no data dealing specifically with plasma. The close correlation of urine and the material in serum which reacts like creatine, however, is reasonably good inferential evidence that the major part of the latter is actually composed of creatine. ${ }^{2}$ The values for serum creatinine obtained in this study agree with those reported by other reliable observers who have used visual colorimetric methods (8).

In both males and females, the urine remained free from creatine so long as the creatine of the serum was lower than $0.58 \mathrm{mgm}$. per cent, with a

2 Dr. Benjamin F. Miller has kindly permitted us to report that Dr. M. J. C. Allison in his laboratory, by the specific enzymatic method of Miller and Dubos, found, in the serum of 9 normal individuals, 0.20 to $0.62 \mathrm{mgm}$. per cent of creatine as creatinine, which agrees well with our own values. 
single exception, a male with hyperthyroidism whose urine contained traces of creatine when the serum creatine was only $0.46 \mathrm{mgm}$. per cent. Creatinuria, therefore, seems to arise when the creatine of the serum rises above a concentration of roughly $0.5 \mathrm{mgm}$. per cent. In normal adult males, the concentration regularly lies below this; consequently, they do not excrete creatine in the urine. In this study, no creatine was found in the urine of a single one of 22 normal adult males. This is in striking contrast to the report by Dill and Horvath (9) that creatinuria regularly occurs in adult males. In large numbers of analyses conducted in this laboratory in the course of the last 20 years by numerous observers, utilizing the Folin technique which is quite accurate for urine, the absence of creatinuria in adult males has been established (unpublished).

A large proportion of normal adult females, however (in this series 13 out of 19), carry in their sera, even in the postabsorptive state, a concentration of creatine exceeding $0.5 \mathrm{mgm}$. per cent, and accordingly excrete creatine constantly in the urine. The smaller proportion who, like males, have less creatine in their sera, resemble the males also in lacking creatinuria, in the postabsorptive state, at least.

Since creatine is a relatively small molecule and presumably exists in a free state in the serum, it may be surmised that it is filtered through the glomeruli and subsequently reabsorbed in the tubules. Its behavior resembles that of glucose in so far as it is completely reabsorbed when it enters the glomerular filtrate at a slow enough rate.

Even when a large dose of creatine is given to a normal male adult, the serum creatine rises only slightly and returns to its initial level with great rapidity. The proportion which finds its way into the urine is extremely small. Apparently, men have other active and efficient methods for disposing of creatine which gains access to the body. It is these mechanisms, presumably, that keep the concentration of creatine so low at ordinary times and that prevent creatine from entering the urine in the course of the day, although moderate amounts of the compound are eaten in most common mixed diets. For it has been established in this laboratory (unpublished) and by numerous other observers, that even 24-hour urine speci- mens of adult males, living on ordinary diets and pursuing normal activities, do not contain detectable amounts of creatine.

Those women who have more than $0.5 \mathrm{mgm}$. of creatine in the serum in the postabsorptive state, when given creatine, develop excessive and prolonged hypercreatinemia and excrete far more of the compound in the urine than males do. The difference between these serum curves and those of the male cannot be attributed to the difference in the initial serum concentrations. The area delimited by the female curve is far greater than that delimited by the male curve. This means that women not only lose a large part of the ingested creatine in their urine, but dispose of the remaining fraction more slowly than the male disposes of the entire dose. This is evident even in those women who have low postabsorptive serum creatine and lack postabsorptive creatinuria. The serum creatine curves of $\mathrm{PH}$ and $\mathrm{DH}$ (Table IV) are far higher than those of the 2 males and the quantities of creatine excreted by them are of an altogether greater order of magnitude. This lesser ability to dispose of creatine probably explains the higher general level of serum creatine in the majority of women and the greater disposition of all women to creatinuria.

With one exception, the patients with hyperthyroidism had creatinuria and with one exception, the serum creatine exceeded $0.50 \mathrm{mgm}$. per cent. In both normal females and hyperthyroid patients, the quantities of creatine excreted in the urine are roughly correlated with its concentration in the serum and the relationships of the two functions in normals and patients are indistinguishable. The male hyperthyroid who had creatinuria with a postabsorptive serum creatine of 0.46 is an exception; but this is a single sporadic observation. On the whole, the evidence indicates that the creatinuria of hyperthyroidism cannot be attributed to any peculiar behavior of the kidneys in this disorder.

There can be no doubt that hyperactivity of the thyroid tends to increase both postabsorptive and alimentary creatinemia. This is evidenced in the reactions of the males and in the response of the females to iodine. There is, however, no sharp qualitative distinction between the hyperthyroids and the normals. Excessive thyroid activity confers on males female characteristics in their be- 
havior towards creatine and, in the female, exaggerates these characteristics. The extrarenal disposition of creatine is impaired or retarded. There is no sharp line separating hyperthyroids from normals. For example, LN, before treatment, had a relatively low fasting serum creatine and excreted less creatine than any one of the 4 normal females in the series.

These data confirm the observation of Palmer, Carson and Sloan (10), that hyperthyroidism induces or exaggerates creatinuria and that this can be allayed by iodine. They give no evidence, however, of any fundamental change in the nature of the metabolism of creatine. Indeed, serum creatine and the alimentary response to creatine may remain normal in the face of severe Graves' disease. An example is seen in Case HS (Tables III and IV), a man who reacted like any normal male. The woman, AL, with myxedema, although she had no postabsorptive creatinuria and a fasting serum creatine in the normal masculine range, as low as any other woman in the normal group, nevertheless reacted like the other women to the ingestion of creatine, developing an alimentary creatinemia and creatinuria comparable to those of normal women and exceeding those of men.

Richardson and Shorr (11) claim that excessive spontaneous and alimentary creatinuria are marks of a particular type of Graves disease, characterized especially by muscular weakness. No evidence of such a sharp distinction could be discerned in this series. The man, HS, with a striking degree of myasthenia, for example, reacted like a normal male. It may be, of course, that no example of the particular type of patient to which Richardson and Shorr refer is included in this series.

The general thesis that creatinuria indicates some disturbance of muscle metabolism is built on tenuous evidence. It is well established that patients with certain disorders of the musculature have excessive creatinuria. An example is found in the patient with peroneal muscular atrophy and it has been demonstrated that this creatinuria was attended by hypercreatinemia. Presumably, this subject produced creatine in excess or, like the hyperthyroid patients, was unable to dispose of it with normal celerity. There is no physiological justification for the inference that this disability is directly related to the muscular pathology. The term disposal has been used above without implications, to indicate merely the known fact that extra creatine introduced into the body disappears without being excreted in the urine. There is no evidence that it accumulates or is destroyed in the muscles $(12,13)$.

The theory that the creatinuria of women is related to their smaller muscle mass implies that production of creatine is the same in all persons and not, like most physiological processes, keyed to the demand. The fact that some Amazons have no creatinuria does not balance the fact that puny males lack it. The cause of the difference between sexes, as well as the disturbances seen in disease, must be sought in other directions and by more searching methods than mere analysis of urine.

No relation could be discovered, in either normal persons or patients, between creatine and creatinine of serum.

Of the mode of excretion of creatine in physiological quantities little is known. Pitts (14) investigated the behavior of the kidneys towards creatine when the concentration of the latter was greatly increased by the parenteral administration of exogenous creatine; but the conditions of his experiments were so unnatural that they have little bearing on physiological phenomena. It has already been pointed out that unless creatine is prevented by some means from passing the glomerular filter, it must be reabsorbed completely by the tubules until the amount delivered to the tubules exceeds a certain minimum which can be defined as the quantity filtered by the average normal person when the concentration of creatine in the serum is about $0.5 \mathrm{mgm}$. per cent. It can be seen from Figure 1 that, as the concentration of creatine in the serum rises above this point, the clearance also tends to rise. The data are too few and the scattering too great to permit any exact deductions about the nature of the curve described. The fact that the concentration in serum is directly related to the clearance indicates, however, that when the quantity of creatine filtered exceeds that which can be completely absorbed, the surplus does not merely escape into the bladder urine. The clearances rise so gradually that obviously reabsorption continues to increase with the quantity of creatine filtered. The proportion of filtered creatine which is reabsorbed must, however, diminish steadily because, by the time its 


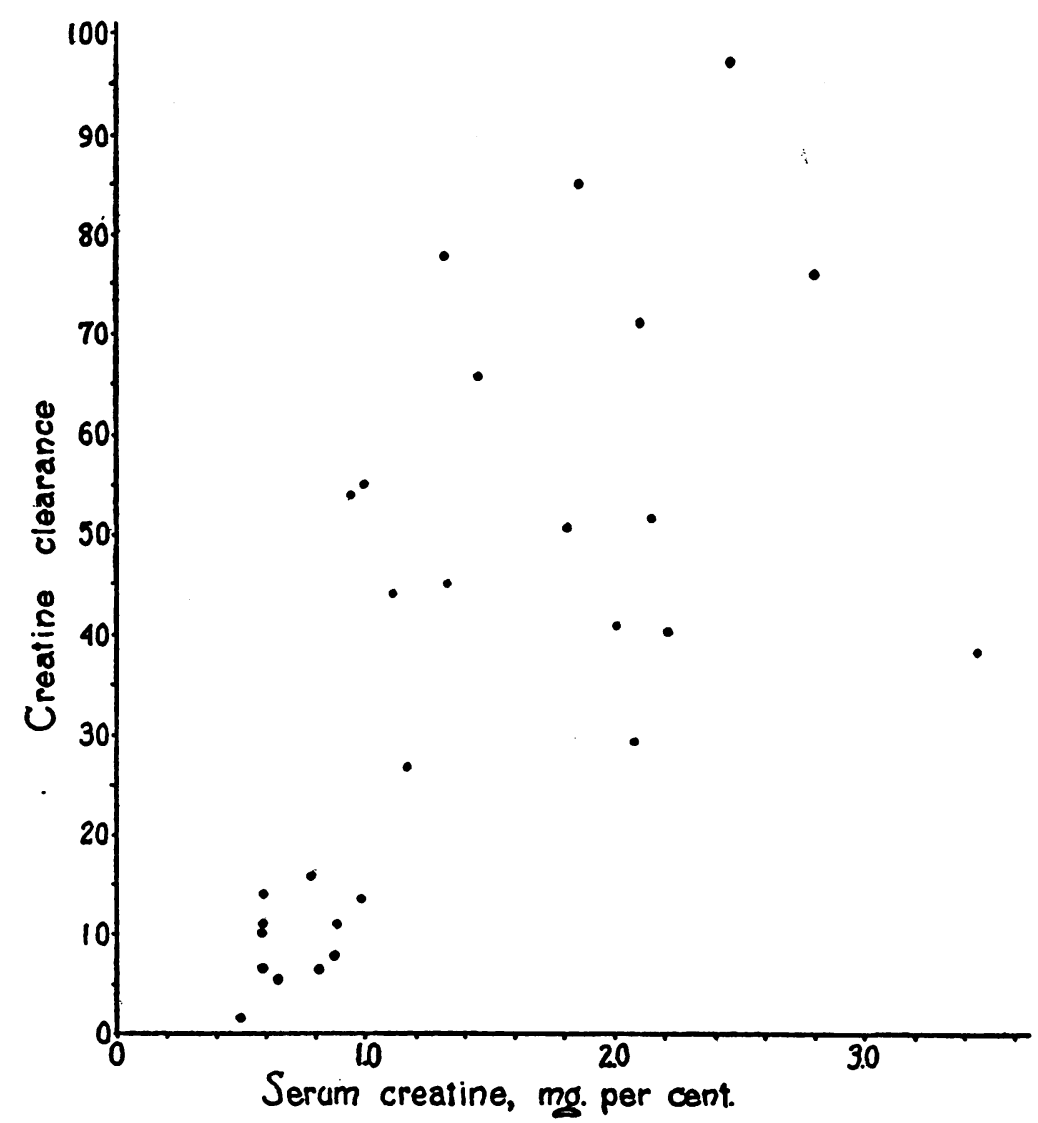

Fig. 1. Relation of Serum Creatine to Creatine Clearance

concentration in the serum has risen only as high as $2 \mathrm{mgm}$. per cent, some of the clearances begin to approach the general magnitude of creatinine clearances. In every instance but one in this whole series, however, the creatinine clearance exceeded the creatine clearance. If the endogenous creatinine clearance in man is, as Miller and Winkler (15) have suggested, a measure of glomerular filtration, it follows that at concentrations attained in the serum in this work, there is no evidence that creatine is secreted by the tubules.

\section{SUMMARY AND CONCLUSIONS}

The concentrations of creatine and creatinine in the serum and urine in the postabsorptive state have been measured in normal adults and in patients with thyroid disease, of both sexes. In addition, clearances of creatine and of endogenous creatinine were measured in similar subjects after the ingestion of 1 gram of creatine. Creatine appeared in the urine only when its concentration in the serum was $0.58 \mathrm{mgm}$. per cent or more. In normal males, it did not exceed this limit. In males, the serum creatine rose little after administration of creatine, and creatinuria was minimal. In women, even if postabsorptive serum creatine was low and creatinuria lacking, administration of creatine induced a greater rise of serum creatine and more creatinuria than it did in males. In hyperthyroidism, postabsorptive serum creatine was usually high and attended by creatinuria. Alimentary creatinemia and creatinuria were exaggerated. Iodine therapy tended to restore these reactions to normal. Creatine is completely reabsorbed by the renal tubules when its concentration in the serum is less than $0.5 \mathrm{mgm}$. per cent. Above this, the clearance of creatine rises as its concentration in the serum increases. In these experiments, the creatine clearance remained always lower than the creatinine clearance. Therefore, no evidence of creatine secretion was obtained. 


\section{BIBLIOGRAPHY}

1. Hunter, A., and Campbell, W. R., The probable accuracy, in whole blood and plasma, of colorimetric determinations of creatinine and creatine. J. Biol. Chem., 1917, 32, 195.

2. Wilson, D. W., and Plass, E. D., Creatine and creatinine in whole blood and plasma. J. Biol. Chem., 1917, 29, 413.

3. Wu, H., Separate analyses of the corpuscles and the plasma. J. Biol. Chem., 1922, 51, 21.

4. Peters, J. H., The determination of creatinine and creatine in blood and urine with the photoelectric colorimeter. J. Biol. Chem., 1942, 146, 179.

5. Folin, O., and $\mathrm{Wu}, \mathrm{H}$., A system of blood analysis. J. Biol. Chem., 1919, 38, 81.

6. Miller, B. F., and Dubos, R., Determination by a specific, enzymatic method of the creatinine content of blood and urine from normal and nephritic individuals. J. Biol. Chem., 1937, 121, 457.

7. Baker, Z., and Miller, B. F., Studies on the metabolism of creatine and creatinine. II. The distribution of creatine and creatinine in the tissues of the rat, dog, and monkey. J. Biol. Chem., 1939, 130, 393.

8. Peters, J. P., and Van Slyke, D. D., Quantitative
Clinical Chemistry. Interpretations. Williams and Wilkins, Baltimore, 1931.

9. Dill, D. B., and Horvath, S. M., The influence of gelatin ingestion upon the creatinine-creatine excretion of normal men. Am. J. Physiol., 1941, 133, 520.

10. Palmer, W. W., Carson, D. A., and Sloan, L. W., The influence of iodine on the excretion of creatine in exophthalmic goiter. J. Clin. Invest., 1929, 6, 597.

11. Richardson, H. B., and Shorr, E., The creatine metabolism in atypical Graves' disease. Tr. A. Am. Physicians, 1935, 50, 156.

12. Chanutin, A., A study of the effect of creatine on growth and its distribution in the tissues of normal rats. J. Biol. Chem., 1927, 75, 549.

13. Bloch, K., and Schoenheimer, R., Studies in protein metabolism. XI. The metabolic relation of creatine and creatinine studied with isotopic nitrogen. J. Biol. Chem., 1939, 131, 111.

14. Pitts, R. F., The clearance of creatine in dog and man. Am. J. Physiol., 1934, 109, 532.

15. Miller, B. F., and Winkler, A. W., The renal excretion of endogenous creatinine in man. Comparison with exogenous creatinine and inulin. J. Clin. Invest., 1938, 17, 31. 